\title{
The Role of Anaerobic Digestion in Reducing Dairy Farm Greenhouse Gas Emissions
}

\author{
Alun Scott and Richard Blanchard * (D) \\ Centre for Renewable Energy Systems Technology, Loughborough University, London E20 3BS, UK; \\ alun.r.scott@gmail.com \\ * Correspondence: r.e.blanchard@lboro.ac.uk; Tel.: +44-1509-227190
}

Citation: Scott, A.; Blanchard, R. The Role of Anaerobic Digestion in Reducing Dairy Farm Greenhouse Gas Emissions. Sustainability 2021, 13 , 2612. https://doi.org/10.3390/ su13052612

Academic Editor: Deepak Pant

Received: 3 December 2020

Accepted: 26 February 2021

Published: 1 March 2021

Publisher's Note: MDPI stays neutral with regard to jurisdictional claims in published maps and institutional affiliations.

Copyright: (C) 2021 by the authors Licensee MDPI, Basel, Switzerland. This article is an open access article distributed under the terms and conditions of the Creative Commons Attribution (CC BY) license (https:// creativecommons.org/licenses/by/ $4.0 /)$.

\begin{abstract}
Greenhouse gas (GHG) emissions from dairy farms are significant contributors to global warming. However, much of the published work on GHG reduction is focused on either methane $\left(\mathrm{CH}_{4}\right)$ or nitrous oxide $\left(\mathrm{N}_{2} \mathrm{O}\right)$, with few, if any, considering the interactions that changes to farming systems can have on both gases. This paper takes the raw data from a year of activity on a 300-cow commercial dairy farm in Northern Ireland to more accurately quantify GHG sources by use of a simple predictive model based on IPCC methodology. Differing herd management policies are examined together with the impact of integrating anaerobic digestion (AD) into each farming system. Whilst significant success can be predicted in capturing $\mathrm{CH}_{4}$ and carbon dioxide $\left(\mathrm{CO}_{2}\right)$ as biogas and preventing $\mathrm{N}_{2} \mathrm{O}$ emissions, gains made can be lost in a subsequent process, negating some or all of the advantage. The process of extracting value from the captured resource is discussed in light of current farm parameters together with indications of other potential revenue streams. However, this study has concluded that despite the significant potential for GHG reduction, there is little incentive for widespread adoption of manure-based farm-scale AD in the UK at this time.
\end{abstract}

Keywords: climate change; greenhouse gas emissions; methane; nitrous oxide; cow manure; anaerobic digestion

\section{Introduction}

Driven by visible evidence of climate change all around us, the concept of sustainability is influencing political and socio-economic choices, with International effort focused on targets to reduce greenhouse gas (GHG) emissions. Signatories to the 2015 Paris Agreement [1] have committed to holding the global temperature increase to well below $2{ }^{\circ} \mathrm{C}$ above pre-industrial levels and pursue efforts to limit the increase to $1.5^{\circ} \mathrm{C}$ in a manner that does not threaten food production. Many countries including the UK and the member states of the European Union have since committed to targets of being climate neutral or net zero by 2050. As part of this effort, it is widely accepted that controlling climate change will not be achieved until the levels of GHG emissions are substantially reduced. Whilst carbon dioxide $\left(\mathrm{CO}_{2}\right)$, the most prevalent long-lived greenhouse gas is the main contributor, substantial progress can be made in slowing the rate of near-term climate change by tackling the three principal short-lived climate forcer (SLCF) pollutants-methane $\left(\mathrm{CH}_{4}\right)$, black carbon, and tropospheric ozone $\left(\mathrm{O}_{3}\right)$ [2]-alongside actions on $\mathrm{CO}_{2}$. As $\mathrm{CH}_{4}$ is the second most common GHG emitted from human activity, this gas is deserving of special focus.

$\mathrm{CH}_{4}$, despite a short 12.4 year atmospheric lifetime, has a Global Warming Potential $\left(\mathrm{GWP}_{100}\right) 28$ times greater than $\mathrm{CO}_{2}$ [3] and is the primary precursor gas of tropospheric ozone that absorbs radiation to become a strong greenhouse gas in the near atmosphere. Taken together, this makes $\mathrm{CH}_{4}$ the most influential GHG after $\mathrm{CO}_{2}$ and the relatively short lifetime means that controlling this gas can yield benefits quickly. By contrast, nitrous oxide $\left(\mathrm{N}_{2} \mathrm{O}\right)$ is a long-lived GHG that has a GWP 100 of 265 times that of $\mathrm{CO}_{2}$ and an atmospheric 
lifetime of 121 years [3], making it a much more persistent cause of climate change that is harder to halt and reverse.

\subsection{The Context of Livestock Farming}

Food production is a sequence of complex biological processes involving multiple GHG interactions from $\mathrm{CO}_{2}$ and $\mathrm{N}$ taken up by growing crops, carbon sequestration in soils, $\mathrm{CH}_{4}$ emissions from livestock, their manures and flooded rice paddies to $\mathrm{N}_{2} \mathrm{O}$ emissions from fertilised land [4]. Amongst all of the data surrounding the sector, the most prominent are the emissions from the global livestock sector, estimated to contribute $14.5 \%$ of all human-induced GHG emissions [4]. The main gases emitted from this sector were $\mathrm{CH}_{4}$ $44 \%, \mathrm{~N}_{2} \mathrm{O} 29 \%$, and $\mathrm{CO}_{2} 27 \%$. Whilst emissions varied by sector and region, emissions from cattle producing beef and milk were significantly greater than any other species. In regions where animal fodder quality was poor, the emissions were greater and productivity levels lower, indicating the importance of animal diet in controlling emissions [4].

Most $\mathrm{CH}_{4}$ from livestock is a by-product of enteric fermentation, largely from ruminant animals (e.g., cattle, sheep, goats), as carbohydrate is digested in the animal gut. Significant quantities are also released as methanogenic bacteria degrade the organic fraction of manure under anaerobic conditions. A study in the Netherlands [5] showed that enteric fermentation is the most important source (approx. $80 \%$ ) of $\mathrm{CH}_{4}$ in dairy husbandry, whereas most $\mathrm{CH}_{4}(>70 \%)$ on pig and poultry farms originates from manures. By comparison, $\mathrm{N}_{2} \mathrm{O}$ is mainly emitted from fertilised land, with additional contribution from aerobic storage and treatment of manures. An estimate of $\mathrm{N}_{2} \mathrm{O}$ emissions in the UK [6] showed that the main sources (approx. 62\%) originate from the soil sector by nitrogen $(\mathrm{N})$ fertiliser and animal manure applications to land and urine deposited by grazing animals. A further $26 \%$ is attributed to leaching and runoff, whilst the remainder is from animal waste management. In the soil sector, $77 \%$ emissions are from fertiliser, $17 \%$ from applied manures and $5 \%$ from grazing animals.

Animal-derived $\mathrm{CO}_{2}$ is considered biogenic by returning to atmosphere $\mathrm{CO}_{2}$ that was captured by plant photosynthesis. However, anthropogenic $\mathrm{CO}_{2}$ that is derived from burning fossil fuels and decomposition of lime applied to pasture is counted in the emissions tally. Ammonia $\left(\mathrm{NH}_{3}\right)$ that is not a recognised GHG is also worthy of mention as it can become an indirect source of $\mathrm{N}_{2} \mathrm{O}$ in the atmosphere. In a Europe wide survey [7], soil-based $\mathrm{NH}_{3}$ emissions from fertiliser application and grazing were lower than $\mathrm{NH}_{3}$ emissions from housing and storage - that opposite is the case for $\mathrm{N}_{2} \mathrm{O}$.

Manure, that is an inevitable by-product of livestock farming, can become a major source of air and water pollution during organic decomposition. $\mathrm{CH}_{4}$ is released when manure is handled under anaerobic conditions, while the formation of $\mathrm{N}_{2} \mathrm{O}$ requires aerobic conditions with access to oxygen. As such, GHG and $\mathrm{NH}_{3}$ can be produced and emitted at each step of the manure management process from generation by livestock, to collection, storage and culminating with manure spreading to land [8], meaning a whole-system approach is required if emissions are to be successfully curtailed, such that savings in one area are not lost in another.

On intensive farms, that commonly do not use bedding materials, the slurry formed by the mix of faeces and urine remains in a predominantly anaerobic state and $\mathrm{CH}_{4}$ dominates. In these slurry-based systems, $\mathrm{NH}_{3}$ losses from concrete yards are also significant and have been estimated to generate almost $10 \%$ of UK and Ireland $\mathrm{NH}_{3}$ emissions [9]. Frequently removing manure from animal houses helps reduce this loss and has also been shown to decrease emissions of $\mathrm{CH}_{4}$ by $55 \pm 5 \%$ and $\mathrm{N}_{2} \mathrm{O}$ by $41 \pm 17 \%$ [10]. In most European countries, and as a result of the EU Nitrates Directive, farms will have sufficient manure storage to span the winter months. At low temperatures, commonly found in outdoor storage, especially in winter, $\mathrm{CH}_{4}$ production is reduced and has been shown to be not significant below $15{ }^{\circ} \mathrm{C}$ [11]. Modelling has predicted that cattle slurry $\mathrm{CH}_{4}$ emissions can be halved by reducing the temperature in slurry channels or by daily emptying to an 
outside store [12]. Consequently, indoor storage and especially that found in houses with slatted floors and slurry pits underneath is likely to have very significant $\mathrm{CH}_{4}$ losses.

The final phase in the process is field application, which is responsible for most of the odour release and is the phase where nutrients are returned to the soil for uptake by growing crops. Application methods that minimise contact of manure with air tend to have lower $\mathrm{NH}_{3}$ emissions, with direct injection seeing a reduction of $73 \%$ and trailing shoe by $57 \%$ on grassland [13], whilst [14] found that $\mathrm{N}_{2} \mathrm{O}$ losses were $20-26 \%$ lower with trailing hose than injection. In a study of application by low-level trailing hose, it was noted that at this stage emissions are dominated by $\mathrm{N}_{2} \mathrm{O}(74-83 \%)$, followed by $\mathrm{NH}_{3}(15-24 \%)$ and $\mathrm{CH}_{4}$ (2-3\%), with most release of $\mathrm{NH}_{3}$ and $\mathrm{CH}_{4}$ in the hours and days after application [15].

\subsection{Anaerobic Digestion}

Anaerobic digestion (AD) has been widely adopted to reduce the polluting effects of sewage and food waste from industrial processes but is a lesser-used pollution reducing technology in the agricultural sector. AD is a natural process that when carried out in a controlled environment enables the ensuing biogas to be captured and used to replace fossil fuels. Biogas is dominated by $\mathrm{CH}_{4}(50-70 \%)$ and $\mathrm{CO}_{2}(30-50 \%)$, with hydrogen sulphide $\left(\mathrm{H}_{2} \mathrm{~S}\right)$ also present in biogas from animal slurries. The bulk of the energy content of the material undergoing degradation is conserved in methane, with only a minor fraction used for bacterial growth and reproduction [16], whilst $\mathrm{CO}_{2}$ has no associated energy. Comparatively, purpose-grown energy crops have a higher biogas potential than manure slurries from which the animal has extracted much of the energy from the original food but slurry does have a positive effect on process stability by contributing a high content of trace elements [17]. Difficult to digest carbon is returned to soil locked in the compounds of the digestate whilst nitrogen loss through volatisation to $\mathrm{NH}_{3}$ or $\mathrm{N}_{2} \mathrm{O}$ is prevented due to the gas-tight environment. In high-nitrogen feedstocks such as grass silage or chicken litter, ammonium can be an inhibitor to the digestion process but managed correctly ammonium nitrate $\left(\mathrm{NH}_{4} \mathrm{NO}_{3}\right)$ concentration is increased, raising the plant-available nitrogen content of the digestate. In 27 months of $\mathrm{AD}$ operation, a $19 \%$ increase [18] in $\mathrm{NH}_{4} \mathrm{NO}_{3}$ was observed compared to raw slurry that when applied to land reduced the quantity of inorganic fertiliser required.

An April 2020 EU report [19] looking at the contribution agriculture can make to the EU's 2030 GHG emission reduction target used the Common Agricultural Policy Regional Impact Analysis (CAPRI) model that considered measures targeted towards the crop and livestock sectors. Within the livestock sector, underlying assumptions from the International Institute for Applied Systems Analysis GAINS model [20] were used; specifically farm-scale anaerobic digestion, changes to animal diet (low-nitrogen feeds and methane-inhibiting additives), genetic improvements (to increase dairy milk yield and improve ruminant feed efficiency) and vaccination against methanogenic bacteria in the rumen.

The report [19] indicated that the greatest reduction was found to be from maximum application of $\mathrm{AD}$ of cattle and pig manures on farms of over 200 livestock units across the EU-28, (-12.7 Mt CO $\left.\mathrm{CO}_{2} \mathrm{eq}\right)$, closely followed by linseed as feed additive (-10.6 $\left.\mathrm{Mt} \mathrm{CO}_{2} \mathrm{eq}\right)$. The reduction in GHG resulted from effectiveness and implementation share, which for $\mathrm{AD}$ across all member states was 35\% (with UK at $14 \%$ and Ireland at $8 \%$ ). The report classified $\mathrm{AD}$ as a high-mitigation, relatively low-cost technology, whereas linseed feed additive was classed high mitigation with high cost. The relatively low implementation rate of $\mathrm{AD}$ in UK/Ireland occurs in part due to the focus on larger farms that are more likely to be able to afford the technology and a higher prevalence of summer pasture grazing.

Year-round confinement is uncommon in the UK and Ireland, where grass-based dairy systems predominate, with $80-95 \%$ and $95-100 \%$, respectively, of herds grazing pasture [21] compared to less than $50 \%$ for Central Europe (Denmark, Germany, Austria) and closer to $20 \%$ for Southern Europe (Spain, Greece, Italy). With animals out grazing, much of the manure is deposited in fields and only a small proportion is collected at milking times. For 
$\mathrm{AD}$, that is a continuous process, and this presents a barrier to more widespread adoption. As manure-based $\mathrm{AD}$ captures most $\mathrm{CH}_{4}$ and achieves the best environmental outcome when fed regularly on fresh manure that has not had time to degrade [22,23], it would not be efficient to store winter-produced slurry for use during the grazing season. Therefore, the potential size of any system on a pasture farm will be limited by the availability of slurry collected during the grazing season, unless another feedstock is available. Co-digestion of maize silage and animal slurry as an AD feedstock is well proven. However, in regions with less favourable weather conditions, growing this crop can cause issues at planting or harvest and there may also be a negative land use change impact from soil carbon losses if converting former grassland into cropland. Grass silage, although of lower energy value than maize, is easier to integrate into a pasture-based farming system and has been shown to be a suitable alternative under Irish conditions [24].

Upon departing the digester, it has been shown that digestate continues to release significant quantities of gas. In a Canadian study [25] of open storage, $\mathrm{CH}_{4}$ emissions amounted to $12 \%$ of biogas collected inside the reactor whilst a Swedish study [26] noted 3 times higher $\mathrm{CH}_{4}$ emissions from digestate than raw slurry from storage over the summer months.

Although AD can occur as a wet or dry process, the majority of plants use wet fermentation that allows for continuous treatment and is a good fit with the slurry disposal needs of intensive livestock farms. In Europe, the most common reactor configuration seen in agriculture is the mesophilic continuously stirred tank reactor (CSTR) that is best suited to substrates of between 2 and 12\% DM [16]. Inside the CSTR, the AD process is dependent on mixing to create a homogenous mixture that keeps solids in suspension, whilst distributing microorganisms, inoculating fresh feed and evening out temperature. Under mesophilic conditions, a typical operating temperature is circa $38^{\circ} \mathrm{C}$, with heat energy a significant input that can be greater in smaller farm scale-based digesters with a higher surface area to volume ratio [27] but is greatly influenced by the initial feedstock temperature, ambient temperature and quality of insulation. Provision of this heat is by burning a proportion of biogas in a dedicated boiler or using a fraction of the heat from a combined heat and power (CHP) unit. The eventual size of the CSTR reactor is dependent on the organic loading rate that tends to be in the range of $1-4 \mathrm{kgVS} / \mathrm{m}^{3} /$ day [16] and hydraulic retention time that depends on the rate of VS degradation. Typical CSTR retention times are approximately 25 to 35 days for animal manures whilst 60 to 90 days is common for fibrous energy crops.

\subsection{Aims and Objectives}

Dairy systems can vary; however, all must face the reality that herd size in a pasture grazing system is limited by the amount of accessible grazing area. To enable herd expansion, cows are often housed for longer periods and fed alternative forages that as a consequence lead to a larger quantity of stored manure to be managed. The aim of this report is to investigate the individual gas sources and the mitigation potential of integrating anaerobic digestion into dairy farming, with specific reference to a commercial farm in Northern Ireland. The principal objectives will be to quantify the GHG production of the case study farm; compare and contrast the environmental merits of this system with that of other widely used dairying systems; evaluate the impact of AD on GHG sources and use the results gained to identify a route towards a 50\% reduction in GHG for the case study farm.

\section{Method and Materials for Estimating Emissions}

To compare differences between dairy systems and take account of operational changes, such as the amount of time cows spend grazing or manure management policy changes, it was necessary to create a bespoke model to quantify the flow of $\mathrm{CH}_{4}$ and $\mathrm{N}_{2} \mathrm{O}$ gases on a monthly basis. Data from a 300-cow dairy unit-see Appendix A-located in Armagh Northern Ireland between April 2019 and March 2020 were used to create 
the reference scenario (RS). By changing model parameters, RS is compared with a more intensive full confinement (FC) and a less intensive pasture grazing (PG) scenario. The herd in the FC scenario is housed year round and fed silage; in RS, they are at housed at night during the grazing season, whilst the PG scenario assumes there is sufficient pasture close to the dairy unit for all-day use during the grazing season.

\subsection{Model Development}

The IPCC 2019 Refinement to the 2006 IPCC Guidelines for National Greenhouse Gas Inventories [28] was chosen to provide a detailed and internationally recognised methodology. With knowledge of feed intake and milk production, the model goes beyond the basic Tier 1 characterisation and adopts a more comprehensive Tier 2 approach that the results from which could then be validated against the National Inventory reports of UK and Ireland.

For simplification, it was assumed that all lactations start and end on the first of the month and cows are at mature weight, avoiding the need to estimate the energy requirement for growth of young cows. The impact of young stock and breeding heifers is also excluded as they are reared separately from the dairy unit.

\subsection{Energy Requirement and Forage Provision}

Quantifying net energy (NE), MJ/cow/day requirements, to provide for bodily maintenance, activity and pregnancy that depend on animal weight and milk production that depends on yield and butterfat content is the starting point of the Tier 2 method and butterfat content are the starting point of the Tier 2 method. Mature cow weight was not known but assumed to be $550 \mathrm{~kg}$, aligning with data for NI dairy cows [29]. NE of grass and grass silage from work in Ireland [30] is taken as representative of farm produced forage, with metabolisable energy from bought-in concentrate converted to NE using the relationship defined by the National Research Council [31]. As cows are fed differing quantities of concentrate depending on milk yield and status, the model calculates a notional intake to arrive at a herd average NE from concentrate per cow per day.

During full-time housing, silage makes up the portion of NE not supplied from concentrate. In the grazing season, milking cows spend $1 / 3$ of the day at pasture and are housed overnight fed on a mixed ration of silage and concentrate whilst dry cows graze all day. On this basis, the model creates a herd average dry matter intake (DMI), kg/cow/day of silage and grass. To ensure best quality silage, only leafy first cut grass is used. However, for the purpose of modelling, the silage area will be adjusted to assume that a given area can produce all forage; see Appendix B.

\subsection{Modelling Methane Emissions}

Following the DMI estimation, the model calculates the gross energy (GE) of the ration using grass, silage and concentrate analysis figures obtained from research [29,30] that allows calculation of enteric $\mathrm{CH}_{4}$ in $\mathrm{kg}$, using IPCC-derived Equation (1), the enteric emission factor $Y_{m}$ from IPCC tables and 55.65, that is the energy content of methane in $\mathrm{MJ} / \mathrm{kg} \mathrm{CH}$.

$$
\text { Enteric } \mathrm{CH}_{4}=\frac{\mathrm{GE} \bullet\left(\mathrm{Y}_{\mathrm{m}} / 100\right)}{55.65}
$$

Using figures for digestibility (D), that is the percentage of GE converted to digestible energy (DE) of the feed and forage, allowed Equation (2) to calculate the excreted volatile solids (VS) as being the proportion of GE consumed that is indigestible. Under IPCC guidance, urinary energy (UE) is 0.04 for ruminant animals; Ash is the mineral fraction of the DMI obtained from feed analysis and 18.45 is the conversion factor for GE per $\mathrm{kg}$ of DM.

$$
\mathrm{VS}=\left[\mathrm{GE} \bullet\left(1-\frac{\mathrm{D}}{100}\right)+(\mathrm{UE} \bullet \mathrm{GE})\right] \bullet[(1-\mathrm{Ash}) / 18.45]
$$


$\mathrm{CH}_{4}$ emitted from manure management uses Equation (3) that employs the maximum $\mathrm{CH}_{4}$-producing capacity of the manure $\left(\mathrm{B}_{0}\right.$, that is given to be 0.24 for European dairy cattle) and allows summation of results from each agricultural waste management system (AWMS) employed using the methane conversion factor (MCF) of each. Multiplying by 0.67 converts the result from $\mathrm{m}^{3} \mathrm{CH}_{4}$ to $\mathrm{kg} \mathrm{CH}_{4}$.

$$
\text { Manure } \mathrm{CH}_{4}=\mathrm{VS}\left[\mathrm{B}_{0} \bullet 0.67 \bullet\left(\sum \mathrm{MCF} / 100 \bullet \mathrm{AWMS}\right)\right]
$$

\subsection{Modelling Nitrous Oxide Emissions}

Using the nitrogen content for feed and forage, less that retained for milk production allowed the excreted nitrogen flow into the manure management system $\left(\mathrm{F}_{\mathrm{MM}}\right)$ to be estimated. The portion of $\mathrm{F}_{\mathrm{MM}}$ lost from storage through direct $\mathrm{N}_{2} \mathrm{O}$ and indirect Frac GAS_MM (Gas Fraction, most initially lost as $\mathrm{NH}_{3}$ ) is calculated using Equation (4) that incorporates emission factor $3\left(\mathrm{EF}_{3}\right)$, the direct emission factor from manure management and emission factor $4\left(\mathrm{EF}_{4}\right)$, the emission factor from surfaces provided for each AWMS from IPCC tables, with $44 / 28$ the conversion for $\mathrm{N}_{2}$ to $\mathrm{N}_{2} \mathrm{O}$ based on atomic weights.

$$
\mathrm{N}_{2} \mathrm{O}_{\mathrm{MM}}=\mathrm{F}_{\mathrm{MM}} \bullet\left[\mathrm{EF}_{3}+\left(\text { Frac }_{\mathrm{GAS}_{\mathrm{MM}}} \bullet \mathrm{EF}_{4}\right)\right] \bullet \frac{44}{28}
$$

$\mathrm{N}_{2} \mathrm{O}$ from field deposited manure classified as Pasture, Range and Paddock (PRP) by the IPCC was calculated taking into account the proportions lost through volatisation at pasture (Frac GAS_PRP $_{\text {S }}$ ) and leaching/runoff (Frac LEACH_PRP $_{\text {L }}$ ) using Equation (5) and emission factor $5\left(\mathrm{EF}_{5}\right)$ the emission factor for nitrogen leaching and runoff.

$$
\mathrm{N}_{2} \mathrm{O}_{\mathrm{PRP}}=\mathrm{F}_{\mathrm{PRP}} \bullet\left[\mathrm{EF}_{3}+\left(\text { Frac }_{\mathrm{GAS}_{\mathrm{PRP}}} \bullet \mathrm{EF}_{4}\right)+\left(\text { Frac }_{\mathrm{LEACH}_{\mathrm{PRP}}} \bullet \mathrm{EF}_{5}\right)\right] \bullet \frac{44}{28}
$$

Using Equation (6), the annual $\mathrm{N}_{2} \mathrm{O}$ emissions from organic animal manure (AM) applications to managed soils were estimated based on the nitrogen $\mathrm{F}_{\mathrm{AM}}$, remaining after the losses in the manure management system; $\mathrm{EF}_{1}$ the emissions factor from animal manure

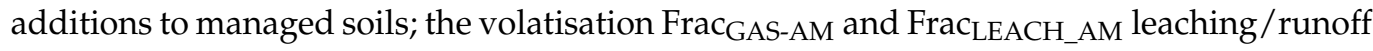
fractions.

$$
\mathrm{N}_{2} \mathrm{O}_{\mathrm{AM}}=\mathrm{F}_{\mathrm{AM}} \bullet\left[\mathrm{EF}_{1}+\left(\text { Frac }_{\mathrm{GAS}_{\mathrm{AM}}} \bullet \mathrm{EF}_{4}\right)+\left(\mathrm{Frac}_{\mathrm{LEACH}_{\mathrm{AM}}} \bullet \mathrm{EF}_{5}\right)\right] \bullet \frac{44}{28}
$$

Finally, the same could be done with Equation (7) for the inorganic fertilisers (synthetic nitrogen, $\mathrm{SN}$ ) applied to grazing and conservation areas with $\mathrm{F}_{\mathrm{SN}}$ being the nitrogen added from fertiliser with specific $\mathrm{EF}_{1}$ volatisation Frac ${ }_{G A S-S N}$ and Frac LEACH_SN $_{\text {S }}$ related to the type of synthetic fertilisers used on the farm.

$$
\mathrm{N}_{2} \mathrm{O}_{\mathrm{SN}}=\mathrm{F}_{\mathrm{SN}} \bullet\left[\mathrm{EF}_{1}+\left(\operatorname{Frac}_{\mathrm{GAS}_{\mathrm{SN}}} \bullet \mathrm{EF}_{4}\right)+\left(\mathrm{Frac}_{\mathrm{LEACH}_{\mathrm{SN}}} \bullet \mathrm{EF}_{5}\right)\right] \bullet \frac{44}{28}
$$

With no land use change or significant changes to grass management during the year, it is assumed soil organic $\mathrm{C}$ is not lost, soil $\mathrm{N}$ is not mineralised to give rise to $\mathrm{N}_{2} \mathrm{O}$ emissions and there are no drained organic soils on the farm that could give rise to $\mathrm{N}_{2} \mathrm{O}$ emissions allowing the focus to be on the animals, the manure and emissions from grassland.

\subsection{Modelling the Anaerobic Digester}

The closed environment of the $\mathrm{AD}$ reactor reduces $\mathrm{CH}_{4}$ and $\mathrm{N}_{2} \mathrm{O}$ emissions. Using IPCC values, the reduced level of $\mathrm{CH}_{4}$ emissions can be determined using Equation (3) with the MCF for AD instead of pit storage. Similarly, specific Frac GAS_AD and $\mathrm{EF}_{3}$ emission factors define $\mathrm{N}_{2} \mathrm{O}$ emissions in Equation (4). As AD works best with a steady feed of VS, it was necessary to calculate the silage feedstock required to make up the shortfall with 
additional nitrogen flow into the reactor from co-digested material added to the $\mathrm{F}_{\mathrm{MM}}$ value and Equation (6) re-worked to establish the new $\mathrm{N}_{2} \mathrm{O}$ emissions.

To determine the biogas production potential, a literature review will be conducted to draw together the published knowledge on the topic and predict the yield based on the VS content of the farm slurry and silage. Once complete, the factors will be loaded into the model that assumes the gas produced is used in a CHP engine, for which a typical thermal efficiency of $55 \%$ and electrical efficiency of $30 \%$ can be expected [32]. Heat consumption of $32 \mathrm{kWh} /$ tonne and electricity demand of $5.4 \mathrm{kWh} /$ tonne [18] are used to calculate the energy requirement of the AD systems.

By changing model parameters, the direct emissions effect of AD on RS can be compared with a FC and a PG scenario. $\mathrm{CH}_{4}$ yields are calculated under each system and converted to units of heat and power to examine the potential savings of $\mathrm{CO}_{2}$.

\section{Results and Discussion}

\subsection{Case Study Farm (Reference Scenario)}

The model highlights that energy and protein are key commodities. Energy quality and quantity defines emissions of $\mathrm{C}$-gas $\left(\mathrm{CH}_{4}\right.$ and $\left.\mathrm{CO}_{2}\right)$ whilst protein content promotes $\mathrm{N}$-gas emissions $\left(\mathrm{N}_{2}, \mathrm{NH}_{3}\right.$ and $\left.\mathrm{N}_{2} \mathrm{O}\right)$. As expected, milk yield was the principal driver of energy requirement constituting approximately $60 \%$ of the cows daily energy need, that peaks early in the lactation before tailing off. Quality of feed as defined by D value is equally significant as cows excrete the indigestible portion of GE as dung. Higher D value feeds such as fresh leafy grass (average D value $77 \%$ ) result in less faecal energy loss and lower enteric emissions than silage (assumed D value $71 \%$ ).

\subsubsection{Methane Emissions}

In the chosen year, the grazing season was approximately 3 weeks shorter than usual due to prevailing weather conditions, with cows turned out to grass on 19 April and housed full time from 16 October resulting in a housed period of 187 days. As total $\mathrm{CH}_{4}$ emissions during the housing period are $392 \mathrm{~g} / \mathrm{cow} /$ day versus $353 \mathrm{~g} / \mathrm{cow} /$ day when cows are at pasture, each additional housing day raises daily emissions by $12 \%$. Despite this issue, and the UK Inventory [33] being derived from a differing methodology, there is only a $2.7 \%$ variance with UK national data; see Table 1 . However, the split between enteric and manure management origin is very different.

Table 1. Comparison of case study farm with regional and national data.

\begin{tabular}{|c|c|c|c|c|c|}
\hline & $\begin{array}{l}\text { IPCC } 2006 \text { Default } \\
\text { (West Europe) }\end{array}$ & $\begin{array}{l}\text { IPCC } 2019 \text { Default } \\
\text { (West Europe) }\end{array}$ & Case Study Farm & $\begin{array}{l}\text { Ireland National } \\
\text { Inventory }\end{array}$ & $\begin{array}{l}\text { UK National } \\
\text { Inventory }\end{array}$ \\
\hline Cow body weight (kg) & 600 & 600 & 550 & 538 & 600 \\
\hline Milk yield (kg/cow/yr) & 6000 & 7410 & 7718 & 5300 & 8120 \\
\hline Digestibility of feed (\%) & 70 & 71 & 77 & 76 & 74.5 \\
\hline $\begin{array}{l}\text { Enteric methane }(\mathrm{kg} \\
\left.\mathrm{CH}_{4} / \mathrm{yr}\right)\end{array}$ & 117 & 126 & 128.26 & 115.21 & 122.71 \\
\hline $\begin{array}{l}\text { Manure management } \\
\text { system }\end{array}$ & $\begin{array}{c}36 \% \text { slurry, } \\
37 \% \text { solid, } \\
20 \% \text { pasture, } \\
7 \% \text { daily spread }\end{array}$ & $\begin{array}{c}43 \% \text { slurry, } \\
29 \% \text { solid, } \\
26 \% \text { pasture, } \\
2 \% \text { daily spread }\end{array}$ & $\begin{array}{l}82 \% \text { pit storage, } \\
18 \% \text { pasture }\end{array}$ & $\begin{array}{c}28 \% \text { pit storage, } \\
70 \% \text { pasture, } \\
2 \% \text { deep bedding }\end{array}$ & $\begin{array}{c}\text { 61\% slurry, } \\
21 \% \text { pasture, } \\
9 \% \text { solid, } \\
8 \% \text { daily spread }\end{array}$ \\
\hline $\begin{array}{l}\text { Manure methane } \\
(\mathrm{kg} / \mathrm{cow} / \mathrm{yr})\end{array}$ & 21 & not stated & 35.88 & 10.36 & 37.26 \\
\hline $\begin{array}{l}\text { Total methane } \\
(\mathrm{kg} / \mathrm{cow} / \mathrm{yr})\end{array}$ & 138.00 & not known & 164.14 & 125.57 & 159.97 \\
\hline $\begin{array}{c}\text { N excreted } \\
(\mathrm{kg} / \text { cow/day })\end{array}$ & 0.288 & 0.324 & 0.401 & 0.282 & 0.301 \\
\hline
\end{tabular}


From Equation (1), GE and emission factor $\mathrm{Y}_{\mathrm{m}}$ drive enteric $\mathrm{CH} 4$ emissions with $\mathrm{Y}_{\mathrm{m}}$ for medium-producing European cows (5000-8500 kg milk/yr) of 6.3 that is linked to a predicted $D$ value of $63-70 \%$, which is much less than the $77 \%$ achieved on farm, indicating a lower $Y_{m}$ might be appropriate. In confirmation, respiration studies [34] have indicated that $Y_{m}$ for Danish cows could be 6.0 that if, applied to the farm would reduce emissions by $6 \mathrm{~kg} \mathrm{CH} 4 /$ yr to align with UK Inventory data.

Considering efficiency of production, the lower input pasture grazing system of Ireland [35] fares worst at $21.73 \mathrm{~g} \mathrm{CH}_{4} / \mathrm{kg}$ milk versus $16.64 \mathrm{~g} \mathrm{CH}_{4} / \mathrm{kg}$ milk for the farm and $15.11 \mathrm{~g} \mathrm{CH}_{4} / \mathrm{kg}$ milk for the UK, indicating that more intensive systems with greater levels of concentrate feed and less reliance on forage help reduce enteric $\mathrm{CH}_{4}$ per unit of production.

On the farm, 3 AWMS were in use: (i) a 6 month pit storage under confinement during winter, (ii) a 3 month pit storage under confinement during grazing season and (iii) a manure deposited on pasture during grazing season that had separate MCFs ranging from $21 \%$ for 6 months pit storage to $0.47 \%$ for manure deposited at pasture. Using Equation (3) and summing for the proportion of manure handled by each AWMS results in a cumulative $35.88 \mathrm{~kg} \mathrm{CH}$ / cow / yr for the farm. The greater time at pasture has a profound effect, with Irelands $\mathrm{CH}_{4}$ levels over $70 \%$ less than either the case study or UK farms.

\subsubsection{Nitrous Oxide Emissions}

The IPCC approach to $\mathrm{N}_{2} \mathrm{O}$ emissions is based on nitrogen excretion, calculated from the crude protein intake of the diet less that retained for milk production or weight gain. As the model assumes cows to be at mature weight, nitrogen retention is only for milk production and consequently may be lower than reality. The farm results are higher than other values in Table 1. However, when excreted nitrogen is expressed per unit of milk production, the farm value becomes $18.96 \mathrm{~g} / \mathrm{L}$, which is comparable to the $19.40 \mathrm{~g} / \mathrm{L}$ reported by Ireland. As excreted nitrogen is highly dependent on diet [36], cows fed a lower crude protein concentrate or maize silage that has low protein content will make more efficient use of this input and could go some way to explaining the $13.5 \mathrm{~g} / \mathrm{L}$ figure reported by the UK.

Direct $\mathrm{N}_{2} \mathrm{O}$ losses from manure storage are low due to lack of oxygen in the anaerobic environment of pit storage with IPCC indication that $0.2 \%$ of manure $\mathrm{N}$ is lost through this route. Indirect emissions account for a more significant nitrogen loss with $28 \%$ as $\mathrm{NH}_{3}$ and NOx gases and a further $0.6 \%$ as $\mathrm{N}_{2}$ gas. In a wet climate, that is typical of UK and Ireland, $14 \%$ of these indirect emissions are deemed to convert to $\mathrm{N}_{2} \mathrm{O}$, which constitutes a combined 0.34 tonne $\mathrm{N}_{2} \mathrm{O}$ per year from pit storage.

In contrast to the $\mathrm{CH}_{4}$ analysis, there was no disaggregation factor for length of storage and so these loss fractions can only be applied on an annual basis. Carrying forward the $28.8 \%$ loss from pit storage, the remaining $\mathrm{N}$ content of the manure is subject to further loss during field application that can vary depending on season of application, weather conditions and application method [37]; but to avoid complication, the IPCC loss of $45 \%$ applied nitrogen has been used, which is composed of $21 \%$ from volatisation during spreading and $24 \%$ from leaching and runoff. $\mathrm{N}_{2} \mathrm{O}$ emissions factors in a wet climate from this nitrogen loss are $0.6 \%$ from manure $\mathrm{N}\left(\mathrm{EF}_{1}\right), 1.4 \%$ from volatisation $\mathrm{N}\left(\mathrm{EF}_{4}\right)$ and $1.1 \%$ for leaching/runoff $\left(\mathrm{EF}_{5}\right)$, with the calculated $\mathrm{N}_{2} \mathrm{O}$ emissions of 0.44 tonne per year using Equation (6). In parallel, manure deposited on pasture by grazing cows emits $\mathrm{N}_{2} \mathrm{O}$ at the same $\mathrm{N}$ loss rates, $\mathrm{EF}_{4}$, and $\mathrm{EF}_{5}$ as for manure spreading with $\mathrm{EF}_{3}$ for cattle manure in a wet climate of $0.6 \%$, which is calculated to be $80 \mathrm{~kg} / \mathrm{yr}$ using Equation (5).

In a significant change from the IPCC 2006 method that assumed a $1 \%$ loss of $\mathrm{N}$ from all inorganic fertiliser, the IPCC 2019 Refinement enables the volatisation of inorganic fertilisers to be split by origin that range from $1 \% \mathrm{~N}$ loss for nitrate based through to $15 \%$ for urea whilst the compound fertilisers used on the farm are from an ammonium nitrate base that has a volatisation fraction of $5 \% \mathrm{~N}$ applied. With $\mathrm{EF}_{1}$ for synthetic fertilisers of $1.6 \%$ and the same soil leaching/runoff fraction, $\mathrm{EF}_{4}$ and $\mathrm{EF}_{5}$ values as for organic manures 
Equation (7) estimates that $30.4 \mathrm{~g} \mathrm{~N}_{2} \mathrm{O}$ are released for every $\mathrm{kg}$ of $\mathrm{N}$ applied. In total, $17.84 \mathrm{t}$ of $\mathrm{N}$ is applied as inorganic fertiliser across the grass area that emits $542 \mathrm{~kg}$ of $\mathrm{N}$ gas. Across the herd, this makes total $\mathrm{N}_{2} \mathrm{O}$ emissions of 1.44 tonne/yr or $4.85 \mathrm{~kg} \mathrm{~N} \mathrm{~N}_{2} \mathrm{O} / \mathrm{cow} / \mathrm{yr}$.

\subsection{Slurry and Silage Results}

Many factors affect the composition of slurry, with diet, feeding system, volume of dirty water, rainwater and any bedding materials contributing to the variance. For the purpose of estimating storage needs in the UK, the quantity of undiluted excreta for a medium-producing (6000-9000 L) cow is considered to be $53 \mathrm{~kg}$ per day [38], rising to $64 \mathrm{~kg}$ per day for higher-yielding cows. Dry solid content of slurry can vary from 2 to $10 \%$, with 6\% [39] considered typical for the UK, whilst in AD studies, total solids have been measured at 8.75\% [40] in Ireland and 6.9\% [18] in Northern Ireland when manure is captured by similar systems as the case study farm. An average figure of $7.2 \%$ has been used for calculations. Crop-available nitrogen in the form of $\mathrm{NH}_{4} \mathrm{NO}_{3}$ is indicated to be $35 \%$ of total nitrogen in raw slurry [39].

On the farm, slurry quantities are not measured. However, with no outside collecting yards to introduce rainwater contamination and milk washings handled separately, the only additions will be dirty water from washing down equipment assumed to be $10 \%$ and spillages from drinking water assumed to be $5 \%$ of excreted manure. Bedding materials of circa $200 \mathrm{~kg}$ per day sawdust across the herd supplement the rubber matted cubicle area, contributing to manure solids that are assumed to be inert. Based on an assumed $61.7 \mathrm{~kg}$ of slurry addition to storage per cow per day during the full-time housing period when average VS was $4.3 \mathrm{~kg} / \mathrm{cow} /$ day, this indicates a VS content of $69.8 \mathrm{~g} / \mathrm{kg}$ slurry that compares to $66.9 \mathrm{~g} / \mathrm{kg}$ slurry for Irish cows [40] and Danish cows at $72.3 \mathrm{~g} / \mathrm{kg}$ slurry [11]. During the grazing season when VS content is lower due to the higher digestibility of fresh grass, the value drops to return an average of $66.4 \mathrm{~g} / \mathrm{kg}$ collected in storage over the year. Whilst dilution could play a part in the variance, it is more likely to be driven by diet, as Irish cows are fed lower levels of concentrate and rely more on fresh grass compared to Danish cows that are often housed year round with a higher reliance on concentrate and silage.

A theoretical prediction of gas yield based on the stoichiometric analysis of the VS fractions of slurry is possible using the Buswell equation. However, the result is based on the assumption that all VS are fully degraded. The reality is often much less and better reflected in a laboratory assessed Biomethane Potential (BMP) of the feedstock. Research in Ireland [40] has found that the Buswell prediction for cow slurry was $389 \mathrm{~L} \mathrm{CH}_{4} / \mathrm{kg}$ VS whilst the measured BMP was $239 \mathrm{~L} \mathrm{CH}_{4} / \mathrm{kg}$ VS and the Buswell prediction for grass silage was $443 \mathrm{~L} \mathrm{CH}_{4} / \mathrm{kg}$ VS, with a measured value of $400 \mathrm{~L} \mathrm{CH}_{4} / \mathrm{kg}$ VS and a VS content of $91.7 \%$ total solids. In separate work [41], two batches of cattle slurry were assessed to have a BMP of 246 and $269 \mathrm{~L} \mathrm{CH}_{4} / \mathrm{kg}$ VS. The BMP of grass silage can also vary depending on grass variety, stage of maturity, success of preservation and measurement accuracy, with a BMP of 359 and 428 recorded for two separate ryegrass silages [41] and 350 and 493 for the same silage sample under differing measurement techniques [42] that subsequently achieved a yield of $451 \mathrm{~L} \mathrm{CH}_{4} / \mathrm{kg}$ VS from mono-digestion of grass silage in a two stage CSTR reactor over a 50 day period. Co-digesting of cattle slurry and grass silage was observed $[40,41]$ to have the antagonistic effect of reducing predicted BMP by an average 7\% that was most pronounced at a 50:50 mix below mono digestion of each substrate.

Averaging the BMP assumptions-see Appendix C-would indicate that the farm slurry can produce $16.7 \mathrm{~L}_{\text {of }} \mathrm{CH}_{4}$ per $\mathrm{kg}$, which is $9 \%$ above the $15.2 \mathrm{~L} \mathrm{CH}_{4} / \mathrm{kg}$ slurry achieved from 2 years AD operation [18], indicating that laboratory figures are difficult to achieve in practice. Assuming farm silage has $24 \% \mathrm{DM}$, that is common for pit silage and $91.7 \%$ of total solids are volatile, the VS content is $220 \mathrm{~g} / \mathrm{kg}$ and using average BMP figures, Appendix $\mathrm{C}$, indicates fresh silage can produce $91 \mathrm{~L} \mathrm{CH}_{4}$ per kg, 5.5 times more than from cow slurry. Allowing for the differences in DM, this ratio is directly equivalent to the 6.7-fold increase [40] recorded with 29\% DM silage. 


\subsection{Results and Discussion of Systems Modelling before and after AD \\ 3.3.1. Systems Comparison before AD}

As expected from the literature, enteric methane dominates at between 71 and $81 \%$ of $\mathrm{CH}_{4}$ emissions depending on farming system employed - see Table 2-and is lowest in the pasture grazing (PG) system that relies most heavily on high digestibility fresh grass. Manure storage $\mathrm{CH}_{4}$ emissions are lowest under the pasture grazing (PG) system, where $80 \%$ of manure is deposited at pasture during the grazing season and only $4114 \mathrm{t}$ of slurry is collected during the year. By comparison, the full confinement (FC) regime collects all $6712 \mathrm{t}$ of slurry produced during the year and produces significantly more from manure management. $\mathrm{N}_{2} \mathrm{O}$ emissions from manure storage and field application follow a similar pattern. However, the PG system has higher $\mathrm{N}_{2} \mathrm{O}$ emissions resulting from the greater amount of pasture deposited manure and increased proportion of grazing land that has higher inorganic fertiliser use with a consequent higher $\mathrm{N}_{2} \mathrm{O}$ emissions. The effect of pollution swapping is clearly visible when comparing the $\mathrm{N}_{2} \mathrm{O}$ emissions that are highest for the PG system, which had the lowest $\mathrm{CH}_{4}$. However, when related back to $\mathrm{CO}_{2}$ eq by using their $\mathrm{GWP}_{100}$ values, the $\mathrm{FC}$ system has the most polluting effect.

Table 2. Dairy herd GHG emissions by source under differing herd and manure management systems.

\begin{tabular}{|c|c|c|c|c|c|c|}
\hline & RS & $\begin{array}{c}\text { RS } \\
\text { with AD }\end{array}$ & FC & $\begin{array}{c}\text { FC } \\
\text { with AD }\end{array}$ & PG & $\begin{array}{l}\text { PG } \\
\text { with AD }\end{array}$ \\
\hline Enteric $\mathrm{CH}_{4}(\mathrm{~kg} / \mathrm{yr})$ & 38,135 & 38,135 & 39,417 & 39,417 & 37,036 & 37,036 \\
\hline Manure Storage $\mathrm{CH}_{4}(\mathrm{~kg} / \mathrm{yr})$ & 10,692 & 653 & 16,019 & 763 & 8751 & 549 \\
\hline Total $\mathrm{CH}_{4}$ emissions $(\mathrm{kg} / \mathrm{yr})$ & 48,827 & 38,788 & 55,436 & 40,180 & 45,787 & 37,585 \\
\hline Manure Storage $\mathrm{N}_{2} \mathrm{O}$ kg/yr) & 344 & 84 & 403 & 91 & 257 & 136 \\
\hline $\begin{array}{l}\text { Manure Field Losses (Spreading, } \\
\text { Leaching, Runoff) } \mathrm{N}_{2} \mathrm{O}(\mathrm{kg} / \mathrm{yr})\end{array}$ & 479 & 708 & 561 & 771 & 357 & 1150 \\
\hline Pasture Losses $\mathrm{N}_{2} \mathrm{O}(\mathrm{kg} / \mathrm{yr})$ & 80 & 80 & 0 & 0 & 191 & 191 \\
\hline Inorganic Fertiliser $\mathrm{N}_{2} \mathrm{O}(\mathrm{kg} / \mathrm{yr})$ & 542 & 537 & 348 & 293 & 666 & 704 \\
\hline Total $\mathrm{N}_{2} \mathrm{O}(\mathrm{kg} / \mathrm{yr})$ & 1444 & 1408 & 1311 & 1155 & 1471 & 2181 \\
\hline Adjusted Land Area Required (ha) & 90 & 104 & 88 & 93 & 90 & 113 \\
\hline $\mathrm{CO}_{2}$ eq (tonne/yr) & 1750 & 1459 & 1900 & 1431 & 1672 & 1630 \\
\hline
\end{tabular}

\subsubsection{Systems Comparison after AD}

The closed environment of the digester enables creation and capture of all volatised gas. However, a percentage will always be lost primarily from operations occurring before manure is loaded into the reactor. $\mathrm{CH}_{4}$ loss is estimated by MCF from IPCC tables [28] that range from $1 \%$ for a high-quality digester with gas-tight storage to $3.55 \%$ for a high-quality digester with open digestate storage in a cool climate. Data from the model in Table 2 are calculated assuming the digestate is stored in a gas-tight environment. IPCC methodology also suggests that $\mathrm{N}$ loss in manure management is reduced from $28 \%$ to $5 \%$ and assuming crop-available $\mathrm{N}$ is increased by $20 \%$ [18] from the $35 \%$ in raw slurry [39], there is a significant nutrient benefit. Although higher $\mathrm{N}$ content digestate increases the losses from land spreading and soil emissions, the model assumes that inorganic $\mathrm{N}$ application across the silage area can be reduced by $20 \%$.

In the reference scenario (RS), the model calculated that $5630 \mathrm{t}$ of slurry is added to storage during the period under consideration. VS production by the herd varies from $43.5 \mathrm{t}$ in March 2020 when the majority of cows are at peak production to $31.8 \mathrm{t}$ in September 2019 that coincides with the lowest number of lactating cows with the low point further reduced to $21.2 \mathrm{t}$ collected into storage due to $1 / 3$ of manure being deposited at pasture. As AD operation is most stable with a continuous feedstock supply, raising VS shortfall 
across the year to the peak of $4.84 \mathrm{~kg} / \mathrm{cow} /$ day seen in March would require the addition of $154 \mathrm{t}$ VS from grass silage that corresponds to $699 \mathrm{t}$ fresh silage ( $24 \% \mathrm{DM}$ ). It is estimated that the required grass silage could be harvested from an additional 14ha of adjusted silage area.

Under the FC scenario, cow numbers and milk yield create the only variation of VS additions to storage, with the model calculating that to maintain the target $4.84 \mathrm{~kg} / \mathrm{cow} /$ day for the 300-cow herd, there is a shortfall of $53 \mathrm{t} \mathrm{VS}$, requiring $243 \mathrm{t}$ of fresh silage. In the PG scenario, where cows graze all day between turnout on 19 April until winter housing on 16 October without any silage feed, $1164 \mathrm{t}$ fresh silage from an additional adjusted silage area of 24 ha is required.

\subsubsection{Sensitivity Analysis}

Sensitivity analysis can be used to assess whether there is uncertainty associated with the model results presented in this study. Due to the nature of the project, the range of input variation will be limited as certain input values are fixed such as the quantity and quality of bought-in concentrate. For example, the project deals with living organisms, cattle, that are part of a commercial agricultural production system with inputs optimised for maximising outputs. However, two key values were investigated that are responsible for the greatest production of $\mathrm{CH}_{4}$. The first was the enteric emission factor $\mathrm{Ym}$, as shown in Table 3, with the values for enteric $\mathrm{CH}_{4}$ and herd enteric $\mathrm{CH}_{4}$ taken from Tables 1 and 2 respectively. It can be seen by altering $\mathrm{Ym}$ that enteric $\mathrm{CH}_{4}$ increases or decreases for all scenarios by the same percentage as the sensitivity change. Increasing $\mathrm{Ym}$ by $5 \%$ increases $\mathrm{CH}_{4}$ levels by $5 \%$ and vice versa. Ym that is driven by genetics is defined by cattle breed and not readily influenced by day-to-day farming activity.

Table 3. The effect of variance in $\mathrm{Ym}$ on enteric $\mathrm{CH}_{4}$ emissions.

\begin{tabular}{|c|c|c|c|c|c|c|}
\hline Ym Variance & & $-5 \%$ & $-2 \%$ & Base & $+2 \%$ & $+5 \%$ \\
\hline Ym (actual figure used in sensitivity calculations) & & 5.98 & 6.17 & 6.3 & 6.43 & 6.62 \\
\hline \multirow[t]{2}{*}{ Reference Scenario } & Enteric $\mathrm{CH}_{4}(\mathrm{~kg} / \mathrm{cow} / \mathrm{yr})$ & 121.85 & 125.7 & 128.26 & 130.83 & 134.67 \\
\hline & Herd Enteric $\mathrm{CH}_{4}(\mathrm{~kg} / \mathrm{yr})$ & 36,228 & 37,372 & 38,135 & 38,897 & 40,041 \\
\hline \multirow[t]{2}{*}{ Full Confinement } & Enteric $\mathrm{CH}_{4}(\mathrm{~kg} / \mathrm{cow} / \mathrm{yr})$ & 125.97 & 129.95 & 132.6 & 135.26 & 139.23 \\
\hline & Herd Enteric $\mathrm{CH}_{4}(\mathrm{~kg} / \mathrm{yr})$ & 37,446 & 38,629 & 39,417 & 40,205 & 41,388 \\
\hline \multirow[t]{2}{*}{ Pasture Grazing } & Enteric $\mathrm{CH}_{4}(\mathrm{~kg} / \mathrm{cow} / \mathrm{yr})$ & 118.32 & 122.05 & 124.55 & 127.04 & 130.77 \\
\hline & Herd Enteric $\mathrm{CH}_{4}(\mathrm{~kg} / \mathrm{yr})$ & 35,185 & 36,296 & 37,036 & 37,777 & 38,888 \\
\hline
\end{tabular}

In addition, the digestibility $\mathrm{D}$ value of the ration was also analysed for sensitivity; see Table 4. The GE of many animal feedstuffs is quite similar, but digestibility of this plant material can vary in cattle, which affects the VS production and hence the $\mathrm{CH}_{4}$ produced from manure storage (Equations (2) and (3)).

Therefore, increasing D decreased VS availability and also decreased $\mathrm{CH}_{4}$. For example, increasing D by $5 \%$ decreased VS by $6.63 \%$ and herd manure $\mathrm{CH}_{4}$ by $6.46 \%$ in RS. For FC, increasing D by 5\% decreased VS by $6.29 \%$ and herd manure $\mathrm{CH}_{4}$ by $6.29 \%$ as well. Finally, for PG, the effect was $6.43 \%$ and $6.34 \%$ respectively. The opposite effect happens when D is decreased with an increase in VS and therefore the amount of $\mathrm{CH}_{4}$ available. The greatest effect, and implications for greenhouse gas emissions would be to the FC strategy which produces the largest amount of $\mathrm{CH}_{4}$. This is important as FC is becoming a more popular system, as herd sizes increase beyond available grazing land and as a route to facilitate the introduction of robotic milking. There is a bit more variation in $\mathrm{D}$ than $\mathrm{Ym}$ and there are small differences between the three strategies. However overall, the model appears to be reliable. 
Table 4. The effect of variance on digestibility of feedstuff on manure management.

\begin{tabular}{|c|c|c|c|c|c|c|}
\hline D Value Variance & & $-5 \%$ & $-2 \%$ & Base & $+2 \%$ & $+5 \%$ \\
\hline \multicolumn{7}{|l|}{ D (actual figures used in sensitivity calculations) } \\
\hline Grass-Early Season (to end May) & & 76.30 & 78.71 & 80.30 & 81.91 & 84.34 \\
\hline Grass-Mid Season (June to August) & & 74.28 & 76.63 & 78.20 & 79.76 & 82.10 \\
\hline Grass-Late Season (September onwards) & & 71.25 & 73.50 & 75.00 & 76.50 & 78.75 \\
\hline Grass Silage & & 67.45 & 69.58 & 71.00 & 72.42 & 74.55 \\
\hline \multirow[t]{4}{*}{ Reference Scenario } & Average D value of ration * & 75.43 & 76.52 & 77.24 & 77.95 & 79.06 \\
\hline & Volatile solids to storage $(\mathrm{kg} / \mathrm{cow} / \mathrm{yr})^{* *}$ & 1339.6 & 1289.6 & 1256.3 & 1223.5 & 1173.0 \\
\hline & Manure Management $\mathrm{CH}_{4}(\mathrm{~kg} / \mathrm{cow})$ & 38.21 & 36.81 & 35.88 & 34.97 & 33.56 \\
\hline & Herd Manure Management $\mathrm{CH}_{4}(\mathrm{~kg} / \mathrm{yr})$ & 11,384 & 10,969 & 10,692 & 10,420 & 10,001 \\
\hline \multirow[t]{4}{*}{ Full Confinement } & Average $\mathrm{D}$ value of ration & 74.47 & 75.51 & 76.21 & 76.91 & 77.96 \\
\hline & Volatile solids to storage $(\mathrm{kg} / \mathrm{cow} / \mathrm{yr})^{* *}$ & 1696.5 & 1636.2 & 1596.10 & 1555.9 & 1495.6 \\
\hline & Manure Management $\mathrm{CH}_{4}(\mathrm{~kg} /$ cow $)$ & 57.29 & 55.25 & 53.9 & 52.54 & 50.5 \\
\hline & Herd Manure Management $\mathrm{CH}_{4}(\mathrm{~kg} / \mathrm{yr})$ & 17,027 & 16,422 & 16,019 & 15,616 & 15,011 \\
\hline \multirow[t]{4}{*}{ Pasture Grazing } & Average $D$ value of ration & 76.1 & 77.21 & 77.95 & 78.69 & 79.8 \\
\hline & Volatile solids to storage $(\mathrm{kg} / \mathrm{cow} / \mathrm{yr})^{* *}$ & 969.32 & 934.17 & 910.74 & 887.31 & 852.15 \\
\hline & Manure Management $\mathrm{CH}_{4}$ (kg/cow) & 31.18 & 30.07 & 29.32 & 28.58 & 27.46 \\
\hline & Herd Manure Management $\mathrm{CH}_{4}(\mathrm{~kg} / \mathrm{yr})$ & 9306 & 8973 & 8751 & 8529 & 8196 \\
\hline
\end{tabular}

* Figure appears in Table 1 of report but is not used in calculations. ${ }^{* *}$ Figure for reference only, does not appear in report but is used by the calculations.

\subsubsection{Discussion}

Whilst $\mathrm{AD}$ can reduce $\mathrm{CH}_{4}$ emissions by $18-28 \%$ depending on the farming system, gas-tight storage is essential as fugitive emissions of only $3.6 \%$ can wipe out any advantage due to the $\mathrm{GWP}_{100}$ of this gas. By comparison, $\mathrm{AD}$ can limit the $\mathrm{N}_{2} \mathrm{O}$ emissions from manure storage by $47-77 \%$ but these gains are not permanent and can be eroded by higher field emissions related to spreading technique or timing that cannot be explored by current IPCC methodology. However, despite field losses, the higher available $\mathrm{N}$ from digestate enables lower inorganic fertiliser use per hectare. In the case of the PG with AD scenario, the very much higher volume of digestate spread to land trebles $\mathrm{N}_{2} \mathrm{O}$ emissions from field losses and increases the $\mathrm{N}_{2} \mathrm{O}$ from inorganic $\mathrm{N}$ applications to the additional silage area grown as an energy crop virtually wiping out any gain from the captured $\mathrm{CH}_{4}$. From an environmental perspective, introducing $\mathrm{AD}$ to a pasture grazed system should therefore only be contemplated if a strategy for controlling $\mathrm{N}_{2} \mathrm{O}$ emissions can be put in place.

Setting aside enteric production, that is best tackled by diet manipulation [36], it is therefore obvious that for slurry-based systems, $\mathrm{CH}_{4}$ emissions are greatest during manure storage, $\mathrm{NH}_{3}$ emissions are greatest from animal confinements and most $\mathrm{N}_{2} \mathrm{O}$ losses occur in the field. Consequently, successful mitigation options for $\mathrm{CH}_{4}$ must target the manure collection and storage systems, $\mathrm{NH}_{3}$ mitigation must focus on building usage and design whilst the priority to reduce $\mathrm{N}_{2} \mathrm{O}$ emissions has to be more efficient fertiliser and manure application to land. Emissions mitigation can take many forms, but care needs to be exercised to avoid unintentional pollution swapping. For example, if $\mathrm{CH}_{4}$ is reduced by increasing the time cattle spend grazing on pasture, pollution swapping occurs, with more $\mathrm{N}_{2} \mathrm{O}$ produced as manures degrades aerobically in the field but indirect emissions of $\mathrm{N}_{2} \mathrm{O}$ will decrease because animals spend less time in housing where $\mathrm{NH}_{3}$ is emitted from manures.

Compared to the RS farm situation of today, introducing AD would reduce GHG emissions by $16.6 \%$, with the best outcome of $24 \%$ reduction from the year-round housed FC scenario. However, if $\mathrm{CO}_{2}$ emissions from silage machinery operations are taken into account, much of this advantage will be lost due to the larger volume of silage required to 
feed the herd year round in the FC system. The PG grazing herd sees the least benefit, as emissions from a big increase in silage area consume almost all gains from AD. In addition, farm-based $\mathrm{AD}$ is preferable to larger industrial reactors as manures are processed on site shortly after production, with minimal loss of gas potential and no fossil fuel $\mathrm{CO}_{2}$ penalty for transporting slurry to a central plant and returning the digestate to the farm. In all instances, if land area is constrained, each additional hectare of energy crop silage required to feed the reactor would require the herd size to reduce by 3.3 cows, impacting on the revenue from milk sales.

\subsection{Creating Value from Biogas \\ 3.4.1. Environmental Considerations}

As the $\mathrm{CO}_{2}$ component of biogas is from a biogenic source that as yet has no commercial value, the impact of this portion of the biogas has been ignored. Focusing on the $\mathrm{CH}_{4}$ each scenario delivers a differing yield, depending on the amount of manure captured and the fraction of VS provided by grass silage. The highest gas yield occurs with the PG scenario that has the largest addition of grass silage during the grazing season, whilst the FC scenario, where the requirement for additional silage is small, has the lowest yield; see Table 5.

At a higher heating value of $37.8 \mathrm{MJ} / \mathrm{m}^{3}$ [16], the energy potential in the captured gas is significant and could be directly realised if injected into the gas grid. For small-scale farm-based digesters, the cost and complexity of this route are often prohibitive, with the result that most are configured with a CHP engine. After providing for the heating, pumping and stirring needs of the reactor, the CHP produces both thermal and electrical energy, with the net figures available for use. The electricity produced is more than the annual 90 MWh requirement of the farm to power the milking machines, cool milk, run the automatic yard scrapers and provide lighting. The dairy has little demand for heat aside from water heating, but with additional infrastructure, a more significant proportion of the heat could be used in the farm dwellings to replace the current kerosene-fuelled central heating systems. In a situation where all of the heat and power generated could be put to productive use, installing an $\mathrm{AD}$ system on the farm would potentially save $715 \mathrm{tCO}_{2}$ per year-see Table 5 - that is a $41 \%$ saving compared to the situation of today. AD has a positive environmental benefit on the three farming systems examined, with GHG savings of between 32 and $44 \% \mathrm{CO}_{2}$ eq achieved. Reductions are greatest for full confinement (FC) herds, with the most manure stored under anaerobic conditions and least for herds that are pasture grazed (PG) on high-quality fresh grass that excrete up to $80 \%$ of manures on pasture during the grazing season.

To achieve an objective of $50 \%$ reduction, other opportunities need to be explored. Instead to release the $\mathrm{CO}_{2}$ that makes up approximately $45 \%$ of biogas back to atmosphere, this gas could be exploited to promote plant growth in glasshouses or to displace fossil fuel $\mathrm{CO}_{2}$ in another industrial process. Alternatively, as the $\mathrm{CO}_{2}$ is captive, there might at some future point be a Carbon Capture and Storage scheme.

Improving the efficiency of $\mathrm{CH}_{4}$ usage could also bring advantages. As the $\mathrm{CHP}$ operates at a combined efficiency of $85 \%$ [32] to produce power and heat beyond the farm needs, diverting a percentage of $\mathrm{CH}_{4}$ for use in tractors, road-going vehicles and other machines to tackle the 40,000 L of diesel consumed annually on the farm and potentially avoid the $110 \mathrm{t} \mathrm{CO}_{2}$ impact (at $2.76 \mathrm{~kg}$ of $\mathrm{CO}_{2}$ eq per litre [43]) would bring immediate benefit. However, whilst methane-powered tractors are nearing commercialisation, there is an obvious need for a small-scale $\mathrm{CH}_{4}$ purification plant to make a farm-based system achievable. 
Table 5. Energy yield and $\mathrm{CO}_{2}$ saving from the $\mathrm{CH}_{4}$ portion of biogas.

\begin{tabular}{|c|c|c|c|}
\hline & RS with AD & FC with AD & PG with AD \\
\hline $\mathrm{CH}_{4}$ yield $\left(\mathrm{m}^{3}\right)$ & 157,544 & 141,173 & 174,211 \\
\hline Gross energy (MWh) & 1654 & 1482 & 1829 \\
\hline Net thermal energy (MWh) & 707 & 593 & 837 \\
\hline Net electrical energy (MWh) & 462 & 407 & 520 \\
\hline $\mathrm{CO}_{2}$ saving from emission reduction (tonne/yr) & 291 & 469 & 42 \\
\hline $\mathrm{CO}_{2}$ saving from $\mathrm{HEAT} *($ tonne/yr) & 193 & 162 & 229 \\
\hline $\mathrm{CO}_{2}$ saving from electricity ** (tonne/yr) & 231 & 203 & 259 \\
\hline TOTAL $\mathrm{CO}_{2}$ saving tonne/yr & $715(41 \%)$ & $834(44 \%)$ & $530(32 \%)$ \\
\hline
\end{tabular}

${ }^{*}$ Basing $\mathrm{CO}_{2}$ savings on $0.27 \mathrm{~kg} \mathrm{CO}$ eq $/ \mathrm{kWh}$ for heat generated from oil fired central heating [44]. ** Basing $\mathrm{CO}_{2}$ savings on the carbon intensity of generation from natural gas at $499 \mathrm{~kg} \mathrm{CO}_{2} \mathrm{eq} / \mathrm{MWh}$ [45].

\subsubsection{Financial Considerations}

As each $\mathrm{AD}$ system is a bespoke design, build costs can vary immensely. Factors affecting capital cost include specific civil works on site, reactor design that is dependent on feedstock characteristics and residence time, together with electricity or gas grid connection and plant needed to purify or convert the gas to usable power. Storage for energy crops can also add to the burden that taking the example of the current farm would need an additional $700 \mathrm{t}$ on top of the existing capacity for $3139 \mathrm{t}$. Consequently, this study did not attempt to estimate these costs but examine potential sources of revenue.

In so far as the author is aware, there is no direct financial reward for pollution reduction from manures in agriculture, and therefore, to be financially viable the revenue from electricity and heat must be sufficient to cover the capital, operational and maintenance costs. Consuming the heat and power on site brings greater benefit than exporting to the grid as displacing electricity bought either at the daytime rate of $16.55 \mathrm{p} / \mathrm{kWh}$ or evening rate of $7.47 \mathrm{p} / \mathrm{kWh}$ is more favourable than exporting to the grid. With approximately $2 / 3$ of electricity bought at the daytime rate and power not consumed on site exported, the farm savings and earnings from grid exportation amount to $£ 29,191$ per year. Savings from heating the three dwelling houses amount to a further $£ 2700$ of avoided kerosene cost, making a total potential revenue of $£ 31,891$ that although significant is unlikely to justify the investment. Regional or national government support could be instrumental in overcoming this hurdle either using capital grants targeted towards the pollution reduction potential of systems or tax breaks to encourage investment. Ongoing enhanced payments could also be used to demonstrate a revenue stream to support bank borrowing but FiTbased systems, unless linked to a carbon reduction incentive, can encourage owners to maximise subsidy payments.

The value of electricity could be increased by a factor of 3 or more if sold direct to a third party through a Power Purchase Agreement (PPA) or to the systems operator for frequency support at times of peak demand. Heat that is an underused resource within the current operation could be exploited by an alternative enterprise either on or off farm to generate an income rather than simply exhausted to atmosphere. Alternatively feeding the grass silage, that has 5.5 times greater $\mathrm{CH}_{4}$ yield per ton than cow slurry, direct to the reactor could substantially increase the FiT or PPA revenue, but this would come at the expense of reducing the size of the dairy herd.

Setting aside the concentrate and grass inputs, each cow in the current system consumes $10.5 \mathrm{t}$ of silage per year to excrete $18.9 \mathrm{t}$ slurry into storage that has the potential to generate $287 \mathrm{~m}^{3}$ of $\mathrm{CH}_{4}$, whereas if the same $10.5 \mathrm{t}$ silage was fed direct to the digester, $956 \mathrm{~m}^{3}$ of $\mathrm{CH}_{4}$ could be produced. Further analysis is required to determine under which circumstances this additional $669 \mathrm{~m}^{3}$ of $\mathrm{CH}_{4}$ could be more valuable than the $7.7 \mathrm{t}$ of milk each cow produces in the year. 


\section{Conclusions}

This study has determined annual GHG emissions from a 300-cow dairy unit in Northern Ireland to be $1750 \mathrm{t} \mathrm{CO}_{2}$ eq made up of $48.8 \mathrm{tCH}_{4}$ and $1.4 \mathrm{t} \mathrm{N}_{2} \mathrm{O}$, with manure management and field loss responsible for $30.8 \%$ of this total. GHG levels are highest as milk production increases, with $\mathrm{CH}_{4}$ levels per litre of milk linked to feed quality and manure storage, whilst $\mathrm{N}_{2} \mathrm{O}$ emissions depend most on dietary protein content and field $\mathrm{N}$ losses.

By modelling alternative farming systems, AD is confirmed as an ideal pollution control, achieving savings of $32-44 \% \mathrm{CO}_{2}$ eq, with the best improvement for full confinement herds. Exploiting the $\mathrm{CO}_{2}$ component of biogas and the ability to use $\mathrm{CH}_{4}$ to power farm vehicles are seen as routes to achieve an objective of $50 \%$ reduction but will require technology advances before becoming an affordable reality.

Despite substantial GHG reduction potential, this study has concluded that farm-scale $\mathrm{AD}$ is not financially viable in the current climate. Capital grants and tax breaks could help overcome high establishment costs whilst funding directed towards pollution control could favour manure-based feedstocks instead of energy crops, enabling AD to make greater contributions towards the $2050 \mathrm{GHG}$ reduction commitments of national governments.

Author Contributions: Conceptualisation, A.S. and R.B.; methodology, A.S. and R.B.; validation, A.S. and R.B.; formal analysis, A.S.; investigation resources, A.S.; data curation, A.S.; writingoriginal draft preparation, A.S.; writing review and editing, R.B. and A.S.; supervision, R.B.; project administration, R.B. and A.S. All authors have read and agreed to the published version of the manuscript.

Funding: This research received no external funding.

Institutional Review Board Statement: Not applicable.

Informed Consent Statement: Not applicable.

Data Availability Statement: Data available on request due to privacy restrictions.

Conflicts of Interest: The authors declare no conflict of interest.

\section{Appendix A. Farm Description}

The case study is of a 300-cow dairy unit located in Armagh, Northern Ireland (NI) over a 12 month period from April 2019 to March 2020. The herd follows a year-round calving pattern, with a 305 day lactation and 2 month dry period prior to calving. Cows are milked twice per day in a rotary parlour and housed in open stall cubicles with pit storage under slatted floors that has 6 months of manure storage capacity. Lactating cows receive a grain-based concentrate feed during milking linked to yield and a lesser amount mixed with the evening silage feed. Dry cows are held separately and fed a lower energy concentrate.

From mid-November to mid-April, all cows are housed on a full-time basis and fed silage in addition to the bought-in concentrate. However, during the grazing season, milking cows graze pasture between morning and evening milking, which is estimated to be $1 / 3$ of the day, and are housed overnight with a ration of $5 \mathrm{~kg}$ silage per cow on a dry matter $(\mathrm{DM})$ basis mixed with additional concentrate, whilst dry cows graze day and night.

The grazing area received 7 applications of $27 \%$ calcium ammonium nitrate (CAN) following the rotational grazing pattern of the herd to deliver $350 \mathrm{~kg} \mathrm{~N} / \mathrm{ha} / \mathrm{yr}$ across the 28 ha of land allocated to grazing. In addition, there are 130 ha that receive spring slurry and $63 \mathrm{kgN} / \mathrm{ha}$ to provide the first cut silage for the dairy herd. Subsequent fertilising and grass harvesting from this silage area provide for the beef enterprise that is outside the scope of this study.

Cow records provide data on herd size and calving date, with milk yield provided from processing plant records, and concentrate delivery data are taken to be indicative of 
consumption rates and available silage sample records assumed to be representative of all ensiled grass.

\section{Appendix B. Grass and Silage Production}

Using data from Recommended Lists [44], the 242 t DM grass requirement of the herd could be met from 24.5 ha grazing area assuming a grazing yield of $9.87 \mathrm{t} \mathrm{DM} / \mathrm{ha}$, and the $753 \mathrm{t}$ DM silage requirement could be met by 103ha at a first cut conservation yield of $7.34 \mathrm{t}$ $\mathrm{DM} /$ ha. However, replicating field trial performance at the farm scale across varying soil types, field aspects, and differing grass varieties will always create discrepancy. In reality, the grazing area is calculated to provide $8.64 \mathrm{tDM} /$ ha $(88 \%$ of potential) and the silage area yield is $5.79 \mathrm{tDM} / \mathrm{ha}(79 \%$ of potential). For the purpose of modelling, the silage area will be adjusted to assume that a given area can produce all the forage at a $79 \%$ factor of the potential annual yield of $15.35 \mathrm{tDM} /$ ha. Under the baseline scenario, this assumption would produce $12.13 \mathrm{tDM} / \mathrm{ha}$ and require 4 cuts from 62 ha land area.

\section{Appendix C. Anaerobic Digester Input Assumptions}

\begin{tabular}{cccc}
\hline \multicolumn{2}{c}{ Slurry Characteristics Kg/cow/day } & \multicolumn{2}{c}{ AD Feedstock Characteristics } \\
\hline Manure excretions & 53 & BMP slurry & $251 \mathrm{~L} \mathrm{CH}_{4} / \mathrm{kg} \mathrm{VS}$ \\
\hline Water additions & 8 & Average VS content of slurry & $66.4 \mathrm{~g} / \mathrm{kg}$ \\
\hline Sawdust bedding & 0.7 & BMP grass silage & $414 \mathrm{~L} \mathrm{CH}_{4} / \mathrm{kg} \mathrm{VS}$ \\
\hline Slurry volume & 61.7 & VS content of silage & $220 \mathrm{~g} / \mathrm{kg}$ \\
\hline
\end{tabular}

\section{References}

1. United Nations Framework Convention on Climate Change (UNFCCC); Paris Agreement: Paris, France, December 2015.

2. Near-Term Climate Protection and Clean Air Benefits: Actions for Controlling Short-Lived Climate Forcers; UNEP: Nairobi, Kenya, 2011; p. 78.

3. Myhre, D.G.; Shindell, F.-M.; Bréon, W.; Collins, J.; Fuglestvedt, J.; Huang, D.; Koch, J.-F.; Lamarque, D.; Lee, B.; Mendoza, T.; et al. Anthropogenic and Natural Radiative Forcing. In Climate Change 2013: The Physical Science Basis. Contribution of Working Group I to the Fifth Assessment Report of the Intergovernmental Panel on Climate Change; Stocker, T.F., Qin, D., Plattner, G.-K., Tignor, M., Allen, S.K., Boschung, J., Nauels, A., Xia, Y., Bex, V., Midgley, P.M., Eds.; Cambridge University Press: Cambridge, UK; New York, NY, USA, 2013.

4. Gerber, P.J.; Steinfeld, H.; Henderson, B.; Mottet, A.; Opio, C.; Dijkman, J.; Falcucci, A.; Tempio, G. Tackling Climate Change through Livestock-A Global Assessment of Emissions and Mitigation Opportunities; Food and Agriculture Organization of the United Nations (FAO): Rome, Italy, 2013.

5. Monteny, G.; Groenestein, C.; Hilhorst, M. Interactions and coupling between emissions of methane and nitrous oxide from animal husbandry. Nutr. Cycl. Agroecosyst. 2001, 60, 123-132. [CrossRef]

6. Brown, L.; Syed, B.; Jarvis, S.; Sneath, R.; Phillips, V.; Goulding, K.; Li, C. Development and application of a mechanistic model to estimate emission of nitrous oxide from UK agriculture. Atmos. Environ. 2002, 36, 917-928. [CrossRef]

7. Oenema, O.; Oudendag, D.; Velthof, G.L. Nutrient losses from manure management in the European Union. Livest. Sci. 2007, 112, 261-272. [CrossRef]

8. Chadwick, D.; Sommer, S.; Thorman, R.; Fangueiro, D.; Cardenas, L.; Amon, B.; Misselbrook, T. Manure Management: Implications for Greenhouse Gas Emissions. Anim. Feed Sci. Technol. 2011, 166-167, 514-531. [CrossRef]

9. Burchill, W.; Reville, F.; Misselbrook, T.H.; O'Connell, C.; Lanigan, G.J. Ammonia emissions and mitigation from a concrete yard used by cattle. Biosyst. Eng. 2019, 184, 181-189. [CrossRef]

10. Sajeev, E.P.M.; Winiwarter, W.; Amon, B. Greenhouse gas and ammonia emissions from different stages of liquid manure management chains: Abatement options and emission interactions. J. Environ. Qual. 2018, 47, 30-41. [CrossRef] [PubMed]

11. Sommer, S.G.; Petersen, S.O.; Sørensen, P.; Poulsen, H.D.; Møller, H.B. Methane and carbon dioxide emissions and nitrogen turnover during liquid manure storage. Nutr. Cycl. Agroecosyst. 2007, 78, 27-36. [CrossRef]

12. Sommer, S.; Petersen, S.; Møller, H. Algorithms for calculating methane and nitrous oxide emissions from manure management. Nutr. Cycl. Agroecosyst. 2004, 69, 143-154. [CrossRef]

13. Misselbrook, T.H.; Smith, K.A.; Johnson, R.A.; Pain, B.F. Slurry Application Techniques to Reduce Ammonia Emissions: Results of Some UK Field-Scale Experiments. Biosyst. Eng. 2002, 81, 313-321. [CrossRef]

14. Thomsen, I.K.; Pedersen, A.R.; Nyord, T.; Petersen, S.O. Effects of slurry pre-treatment and application technique on short-term $\mathrm{N} 2 \mathrm{O}$ emissions as determined by a new non-linear approach. Agric. Ecosyst. Environ. 2010, 136, 227-235. [CrossRef] 
15. Clemens, J.; Trimborn, M.; Weiland, P.; Amon, B. Mitigation of greenhouse gas emissions by anaerobic digestion of cattle slurry. Agric. Ecosyst. Environ. 2006, 112, 171-177. [CrossRef]

16. Murphy, J.; Thamsirioj, T. Chapter 5-Fundamental Science and Engineering of the Anaerobic Digestion Process for Biogas Production. In The Biogas Handbook: Science, Production and Applications; Wellinger, A., Murphy, J., Baxter, D., Eds.; Woodhead Publishing: Oxford, UK, 2013; pp. 104-130.

17. Weiland, P. Biomass digestion in agriculture: A successful pathway for the energy production and waste treatment in Germany. Eng. Life Sci. 2006, 6, 302-309. [CrossRef]

18. Frost, P.; Gilkinson, S. Interim Technical Report-27 Month Performance Summary for Anaerobic Digestion of Dairy Cow Slurry at AFBI Hillsborough; Agri-Food and Biosciences: Hillsborough, UK, March 2010.

19. Domínguez, I.P.; Fellmann, T.; Witzke, P.; Weiss, F.; Hristov, J.; Himics, M.; Barreiro-Hurle, J.; Barbero, M.G.; Leip, A. Economic Assessment of GHG Mitigation Policy Options for EU Agriculture: A Closer Look at Mitigation Options and Regional Mitigation Costs (EcAMPA 3); EUR 30164 EN; JRC120355; Publications Office of the European Union: Luxembourg, April 2020; ISBN 978-92-76-17854-5. [CrossRef]

20. Hoglund-Isaksson, L.; Winiwarter, W.; Purohit, P.; Gomez-Sanabria, A. Non-CO2 Greenhouse Gas Emissions in the EU-28 from 2005 to 2050: Final GAINS Reference Scenario 2016. GAINS Model Methodology. IIASA Report; International Institute for Applied Systems Analysis: Laxenburg, Austria, 2016.

21. Dasselaar, A.V.D.P.-V.; Hennessy, D.; Isselstein, J. Grazing of dairy cows in europe-An in-depth analysis based on the perception of grassland experts. Sustainability 2020, 12, 1098. [CrossRef]

22. Coppolecchia, D.; Gardoni, D.; Baldini, C.; Borgonovo, F.; Guarino, M. The influence on biogas production of three slurry-handling systems in dairy farms. J. Agric. Eng. 2015, 46, 30-35. [CrossRef]

23. Vergote, T.L.I.; Vanrolleghem, W.J.C.; Van der Heyden, C.; De Dobbelaere, A.E.J.; Buysse, J.; Meers, E.; Volcke, E.I.P. Model-Based Analysis of Greenhouse Gas Emission Reduction Potential through Farm-Scale Digestion. Biosyst. Eng. 2019, 181, 157-172. [CrossRef]

24. Himanshu, H.; Murphy, J.D.; Lenehan, J.J.; O'Kiely, P. Impacts of characteristics of grass silage and cattle slurry feedstocks on the cost of methane production. Biofuels Bioprod. Biorefining 2018, 13, 129-139. [CrossRef]

25. Baldé, H.; Vanderzaag, A.C.; Burtt, S.D.; Wagner-Riddle, C.; Crolla, A.; Desjardins, R.L.; Macdonald, D.J. Methane emissions from digestate at an agricultural biogas plant. Bioresour. Technol. 2016, 216, 914-922. [CrossRef]

26. Rodhe, L.K.; Ascue, J.; Willén, A.; Persson, B.V.; Nordberg, Å. Greenhouse gas emissions from storage and field application of anaerobically digested and non-digested cattle slurry. Agric. Ecosyst. Environ. 2015, 199, 358-368. [CrossRef]

27. Lukehurst, C.; Bywater, A. Exploring the Viability of Small-Scale Anaerobic Digesters in Livestock Farming; IEA Bioenergy: Paris, France, 2015; Available online: https:/ /www.ieabioenergy.com/wp-content/uploads/2015/12/Small_Scale_RZ_web2.pdf (accessed on 1 September 2020).

28. Intergovernmental Panel on Climate Change (IPCC) - IPCC 2019, Refinement to the 2006 IPCC Guidelines for National Greenhouse Gas Inventories. Available online: https:/ / www.ipcc.ch/report/2019-refinement-to-the-2006-ipcc-guidelines-for-nationalgreenhouse-gas-inventories (accessed on 12 June 2020).

29. Hynes, D.N.; Stergiadis, S.; Gordon, A.; Yan, T. Effects of Crude Protein Level in Concentrate Supplements on Animal Performance and Nitrogen Utilisation of Lactating Dairy Cows Fed Fresh Cut Perennial Grass. J. Dairy Sci. 2016, 99, 8111-8120. [CrossRef] [PubMed]

30. O'Mara, F.P. Climate Change—Development of Emission Factors for the Irish Cattle Herd, Special Report; Environmental Protection Agency: Johnstown Castle, Ireland, 2006.

31. National Research Council. NRC (2001) Nutrient Requirements of Dairy Cattle: Seventh Revised Edition, 2001; The National Academies Press: Washington, DC, USA, 2001; p. 13.

32. O'Connor, S.; Ehimen, E.; Pillai, S.C.; Lyons, G.; Bartlett, J. Economic and environmental analysis of small-scale anaerobic digestion plants on Irish dairy farms. Energies 2020, 13, 637. [CrossRef]

33. Richmond, B.; Misra, A.; Broomfield, M.; Brown, P.; Karagianni, E.; Murrells, T.; Pang, Y.; Passant, N.; Pearson, B.; Stewart, R.; et al. UK Informative Inventory Report (1990-2017); DEFRA: London, UK, April 2019.

34. Hellwig, A.L.F.; Weisbjerg, M.R.; Brask, M.; Astrup, L.; Johansen, M.; Hymøller, L.; Larsen, M.K.; Lund, P. Prediction of the Methane Conversion Factor $\left(\mathrm{Y}_{\mathrm{m}}\right)$ for Dairy Cows on the Basis of National Farm Data. Anim. Prod. Sci. 2016, 56, 535-540. [CrossRef]

35. Duffy, P.; Hyde, B.; Ryan, A.M.; Murphy, J.; Quirke, B.; Fahey, D. Ireland Informative Inventory Report 2019; Environment Protection Agency: Johnstown Castle, Ireland, 2019.

36. Misselbrook, T.; Del Prado, A.; Chadwick, D. Opportunities for reducing environmental emissions from forage-based dairy farms. Agric. Food Sci. 2013, 22, 93-107. [CrossRef]

37. Thorman, R.E.; Nicholson, F.A.; Topp, C.F.E.; Bell, M.J.; Cardenas, L.M.; Chadwick, D.R.; Cloy, J.M.; Misselbrook, T.H.; Rees, R.M.; Watson, C.J.; et al. Towards country-specific nitrous oxide emission factors for manures applied to arable and grassland soils in the UK. Front. Sustain. Food Syst. 2020, 4. [CrossRef]

38. Agriculture and Horticulture Development Board (AHDB), Slurry. Available online: http://www.ahdb.org.uk/knowledgelibrary / slurry-wizard (accessed on 24 July 2020). 
39. Agriculture and Horticulture Development Board. AHDB Nutrient Management Guide (RB209), February 2020 edition. Available online: https: / /ahdb.org.uk/RB209 (accessed on 11 August 2020).

40. Wall, D.M.; O'Kiely, P.; Murphy, J.D. The potential for biomethane from grass and slurry to satisfy renewable energy targets. Bioresour. Technol. 2013, 149, 425-431. [CrossRef] [PubMed]

41. Himanshu, H.; Murphy, J.; Grant, J.; O'Kiely, P. Antagonistic effects on biogas and methane output when co-digesting cattle and pig slurries with grass silage in in vitro batch anaerobic digestion. Biomass Bioenergy 2018, 109, 190-198. [CrossRef]

42. Nizami, A.S.; Orozco, A.; Groom, E.; Dieterich, B.; Murphy, J.D. How much gas can we get from grass? Appl. Energy 2012, 92, 783-790. [CrossRef]

43. Department for Business, Energy and Industrial Strategy-UK Government. Greenhouse Gas Reporting: Conversion Factors 2020. Available online: https://www.gov.uk/government/publications/greenhouse-gas-reporting-conversion-factors-2020 (accessed on 30 August 2020).

44. British Grassland Society. Recommended Grass and Clover Lists for England and Wales; British Grassland Society: Nantwich, UK, 2020.

45. Gridwatch.co.uk-GB Electricity National Grid CO2e Output per production type. Available online: https://gridwatch.co.uk/ co2-emissions (accessed on 30 August 2020). 